\title{
Potensi Tindak Pidana Kriminal oleh Anak Remaja ditinjau dari Faktor Umur dan Pendidikan dengan Metode Multi Factor Evaluation Process (MFEP)
}

\author{
${ }^{1)}$ Riswan Limbong \\ STMIK Budi Darma Medan, JI. SM.Raja No.338 Sp.Limun Medan, Sumut, Indonesia \\ E-Mail: riswanlimbong@gmail.com \\ ${ }^{2)}$ Kristian Siregar \\ STMIK Budi Darma Medan, JI. SM.Raja No.338 Sp.Limun Medan, Sumut, Indonesia \\ E-Mail: kristianregar@gmail.com
}

\begin{abstract}
According to statistics in 2013 there were 535 cases and in 2014 there were 723 cases, and based on the data there was an increase of $\pm 1.35 \%$. The cause of this crime is caused by many factors, but if the factors that cause this crime are known to be earlier by the parents (community), perhaps parents can educate their children and can reduce the number of juvenile perpetrators of physical criminal offenses. The physical crimes referred to in this study are: Robbery, Public order theft and murder.

Multifactor Evaluation Process (MFEP) is a quantitative method that uses a "weighting system". In multifactorial decision making, decision makers are subjectively and intuitively weighing various factors that have an important influence on their alternative choices. For decisions that have a strategic influence, it is advisable to use a quantitative approach such as MFEP. In MFEP, all criteria are first, which are important factors in making consideration given appropriate weighting. The same steps are also taken for the alternatives to be chosen, which can then be evaluated in relation to these consideration factors. The MFEP method determines that the alternative with the highest value is the best solution based on the selected criteria.

Kata Kunci : Tindak Kriminal Fisik, Kenakalan Remaja, MFEP, Sistem Pendukung Keputusan
\end{abstract}

\section{PENDAHULUAN}

Remaja adalah bagian dari generasi muda merupakan suatu kekuatan sosial yang sangat berperan dalam pembangunan bangsa dan negara. Di tangan generasi muda terletak masa depan bangsa yang kelak akan menjadi pemimpin dalam membangun hari depan yang lebih baik. Sebagai generasi penerus perjuangan bangsa Indonesia yang mempunyai hak dan kewajiban ikut serta dalam membangun negara dan bangsa Indonesia, generasi muda dalam hal ini remaja merupakan subyek dan obyek pembangunan nasional dalam usaha mencapai tujuan bangsa Indonesia yaitu mewujudkan masyarakat yang adil dan makmur.

Remaja merupakan modal pembangunan yang akan memelihara dan mengembangkan hasil pembagunan baik fisik maupun mental sosial Indonesia yang harus ditumbuhkembangkan sebagai manusia seutuhnya, sehingga mempunyai kemampuan untuk melaksanakan hak dan kewajibannya sebagai warga negara Indonesia yang senantiasa memiliki tanggungjawab dan bermanfaat sesuai dengan Pancasila dan UUD 1945.

Berdasarkan ketentuan dari pihak sekolah, untuk hasil rekomendasi kelompok campuran, pilihan pertama dan pilihan kedua berasal dari program studi saintek, sedangkan pilihan ketiga dari program studi soshum. Pada tabel 15 dapat dilihat bahwa walaupun nilai weight evaluation program studi Teknik Geologi dan program studi Teknik Arsitektur lebih kecil dari weight evaluation program studi Manajemen atau IImu Administrasi Negara, tetap saja pilihan pertama dan kedua berasal dari program studi saintek. Karena berdasarkan ketentuan, untuk pilihan pertama dan kedua rekomendasinya hanya dari kelompok program studi saintek, selanjutnya adalah program studi dari kelompok soshun. Hasil dari rekomendasi pemilihan program studi ini, bukanlah hasil mutlak bahwa siswa harus memilih program studi yang direkomendasikan, tetapi hasil rekomendasi ini hanya sebagai pendukung keputusan bagi siswa dalam memilih program studi yang diminatinya. Karena pengambilan 
keputusan dikembalikan lagi kepada siswa yang bersangkutan [2].

\section{LANDASAN TEORI}

\subsection{Kriminologi}

Kriminologi sebagai ilmu pembantu dalam hukum pidana yang memberikan pemahaman yang mendalam tentang fenomena kejahatan, sebab dilakukannya kejahatan dan upaya yang dapat menanggulangi kejahatan, yang bertujuan untuk menekan laju perkembangan kejahatan. Seorang antropolog yang berasal dari Prancis, bernama Paul Topinard mengemukakan bahwa "Kriminologi adalah suatu cabang ilmu yang mempelajari soal-soal kejahatan. Kata Kriminologi itu sendiri berdasar etimologinya berasal dari dua kata, crimen yang berarti kejahatan dan logos yang berarti ilmu pengetahuan, sehingga secara sederhana Kriminologi dapat diartikan sebagai ilmu pengetahuan yang mempelajari kejahatan [12].

Kriminologi sebagai salah satu disiplin ilmu sosial menelaah gejala dan tingkah laku anggota masyarakat dari sudut tertentu yaitu dari segi pola, motivasi, serta usaha menanggulangi kejahatan. Kriminologi adalah ilmu pengetahuan yang mempelajari gejalagejala kejahatan seluas-luasnya (kriminologi teoritis dan kriminologi murni). Kriminilogi teoritis adalah ilmu pengetahuan yang berdasarkan pengalaman, yang seperti ilmuilmu pengetahuan lainnya yang sejenis, memperhatikan gejala-gejala dan mencoba menyelidiki krminologi teoritis disusun kriminologi terapan.

Kriminologi menurut Soedjono

Dirdjosisworo adalah ilmu pengetahuan yang mempelajari sebab, akibat, perbaikan dan pencegahan kejahatan sebagai gejala manusia dengan menghimpun sumbangan-sumbangan berbagai ilmu pengetahuan. Tegasnya, Kriminologi merupakan sarana untuk mengetahui sebab-sebab kejahatan dan akibatnya, mempelajari cara-cara mencegah kemungkinan timbulnya kejahatan [4], menyatakan bahwa kriminologi adalah studi ilmiah tentang kejahatan dan penjahat yang mencakup analisa tentang :

a. Sifat dan luas kejahatan

b. Sebab-sebab kejahatan

c. Perkembangan hukum pidana dan pelaksanaan peradilan pidana

d. Ciri-ciri penjahat

e. Pembinaan penjahat

f. Pola-pola kriminalitas, dan

g. Akibat kejahatan atas perubahan sosial

Kriminologi adalah ilmu pengetahuan mengenai sikap tindak kriminal. Sehubungan itu beliau menjelaskan pula bahwa Kriminologi modern berakar dari sosiologi, psikologi, psikiatri dan ilmu hukum yang ruang lingkupnya meliputi :

a. Hakekat, bentuk-bentuk dan frekuansi-frekuensi perbuatan kriminal sesuai dengan distribusi sosial, temporal dan geografis.

b. Karakteristik-karakteristik fisik, psikologis, sejarah serta. sosial penjahat dan hubungan antara. kriminalitas dengan tingka laku abnormal lainnya.

c. Karakteristik korban-korban kejahatan.

d. Tingkah laku non kriminal anti sosial, yang tidak semua masyarakat dianggap, sebagai kriminalitas.

e. Prosedur sistem peradilan pidana

f. Metode-metode hukuman, latihan dan penanganan narapidana

g. Struktur sosial dan organisasi lembaga-lembaga penal

h. Metode-metode pengendalian dan penanggulangan kejahatan

i. Metode-metode identifikasi kejahatan dan penjahat

j. Studi mengenai asas dan perkembangan hukum pidana serta. sikap umum terhadap kejahatan dan penjahat.

\subsection{Pengertian Tindak Pidana dan Unsur- Unsurnya}

Tindak Pidana atau delik berasal dari bahasa Latin delicta atau delictum yang dikenal dengan istilah strafbar feit dan dalam KUHP (Kitab Undang-Undang Hukum Pidana) dengan perbuatan pidana atau peristiwa pidana. Kata Strafbar feit inilah yang melahirkan berbagai istilah yang berbeda-beda dari kalangan ahli hukum sesuai dengan sudut pandang yang berbeda pula. Ada yang menerjemahkan dengan perbuatan pidana, tindak pidana dan sebagainya. Dari pengertian secara etimologi ini menunjukan bahwa tindak pidana adalah perbuatan kriminal, yakni perbuatan yang diancam dengan hukuman. Dalam pengertian ilmu hukum, tindak pidana dikenal dengan istilah crime dan criminal.

Dalam Kamus Besar Bahasa Indonesia, kata pidana berarti hukuman kejahatan tentang pembunuhan, perampokan, korupsi dan lain sebagainya. Pidana juga berarti hukuman. Dengan demikian, kata mempidana berarti menuntut berdasarkan hukum pidana, menghukum seseorang karena melakukan tindak pidana. Dipidana berarti dituntut berdasarkan hukum pidana, dihukum berdasarkan hukum pidana, sehingga terpidana berarti orang yang dkenai hukuman.

Peristiwa pidana itu adalah sesuatu perbuatan atau rangkaian perbuatan manusia, 
yang bertentangan dengan Undang-undang atau peratturan perundang-undangan lainnya, terhadap perbuatan mana diadakan tindakan penghukuman, menyatakan bahwa dalam peristiwa pidana itu mempunyai syarat-syarat [7], yaitu: a). Harus ada suatu perbuatan manusia, b). Perbuatan itu harus sesuai dengan apa yang dilukiskan didalam ketentuan hukum. c). Harus terbukti adanya "dosa" pada orang yang berbuat, yaitu orangnya harus dapat dipertanggungjawabkan, d). Perbuatan itu harus berlawanan dengan hukum. e). Terhadap perbuatan itu harus tersedia ancaman hukumannya dalam undang-undang.

\subsection{Metode Multifactor Evaluation Process (MFEP)}

Multifactor Evaluation Process (MFEP) adalah metode kuantitatif yang menggunakan "weighting system". Dalam pengambilan keputusan multifaktor, pengambil keputusan secara subyektif dan intuitif menimbang berbagai faktor yang mempunyai pengaruh penting terhadap alternative pilihan mereka. Untuk keputusan yang berpengaruh secara strategis, lebih dianjurkan menggunakan sebuah pendekatan kuantitatif seperti MFEP [6][9]. Dalam MFEP pertama-tama seluruh kriteria, yang menjadi faktor penting dalam melakukan pertimbangan diberikan pembobotan (weighting) yang sesuai. Langkah yang sama juga dilakukan terhadap alternatifalternatif yang akan dipilih, yang kemudian dapat dievaluasi berkaitan dengan faktor-faktor pertimbangan tersebut. Metode MFEP menentukan bahwa alternatif dengan nilai tertinggi adalah solusi terbaik berdasarkan kriteria yang telah dipilih.

MFEP merupakan model pengambilan keputusan yang menggunakan pendekatan kolektif dari proses pengambilan keputusannya (Render dan Stair, 2002).

Di bawah ini merupakan langkah-langkah proses perhitungan menggunakan metode MFEP, yaitu:

1. Menentukan faktor dan bobot faktor dimana total pembobotan harus sama dengan $1(\Sigma$ pembobotan $=1$ ), yaitu factor weight.

2. Mengisikan nilai untuk setiap faktor yang mempengaruhi dalam pengambilan keputusan dari data-data yang akan diproses nilai yang dimasukkan dalam proses pengambilan keputusan merupakan nilai objektif, yaitu sudah pasti yaitu factor evaluation yang nilaianya antara 01.

3. Proses perhitungan weight evaluation yang merupakan proses perhitungan bobot antara factor weight dan factor evaluation dengan serta penjumlahan seluruh hasil weight evaluations untuk memperoleh total hasil evaluasi.

Penggunaan model MFEP dapat direalisasikan:

1. $W E=F W \times E$

2. $\Sigma W E=\Sigma(F W \times E)$

Keterangan :

1. $\mathrm{WE}=$ Weighted Evaluation

2. $\mathrm{FW}=$ Factor Weight

3. $E=$ Evaluation

4. $\sum W E=$ Total Weighted Evaluation

\section{METODE PENELITIAN}

Desain dan tahapan penelitian yang dilaksanakan peneliti untuk memudahkan tahapan pelaksanaan dapat dilihat dengan menggunakan gambar 1 berikut:

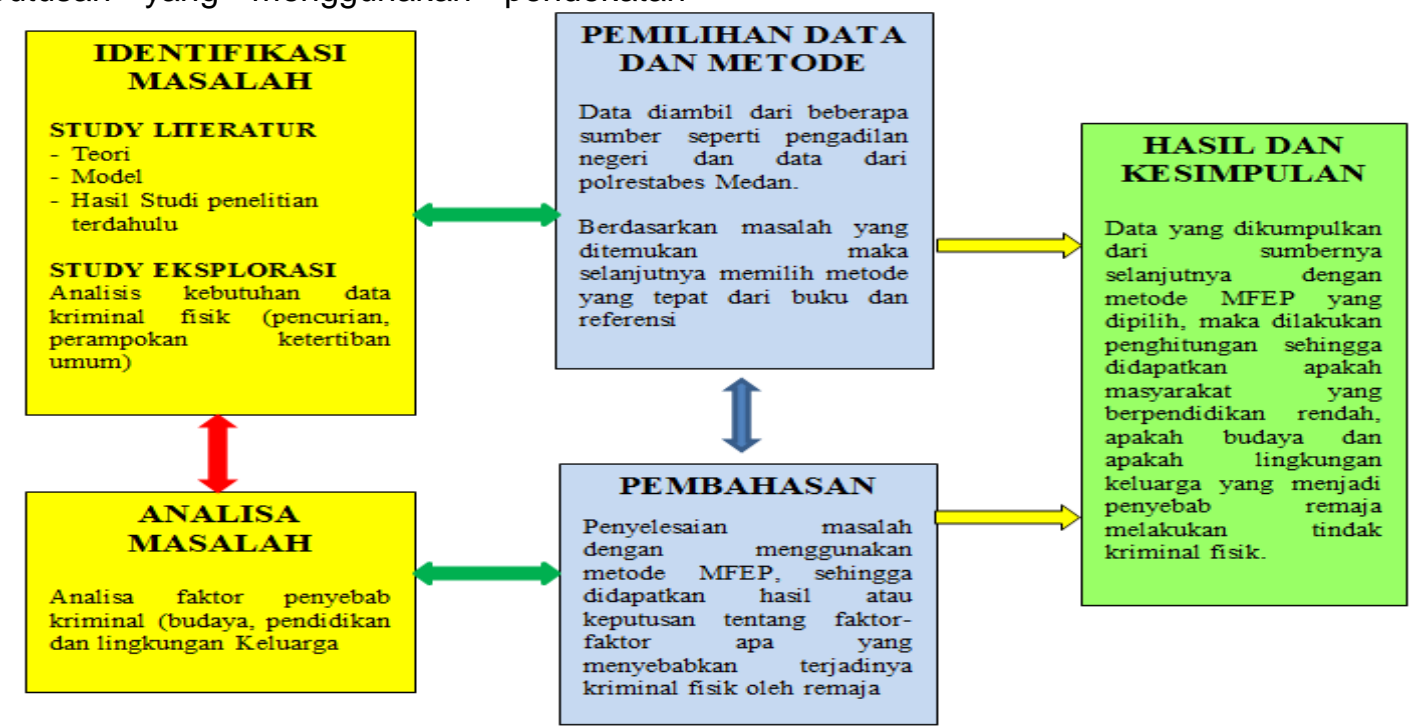

Gambar 1. Diagram Desain Metode dan Tahapan Penelitian 


\begin{abstract}
Penelitian tentang tinjauan
kriminologis terhadap tindak pidana kriminal fisik oleh remaja di Kota Medan adalah Empiris yaitu adalah penelitian berdasarkan fakta-fakta yang ada di dalam masyarakat mengenai faktor-faktor yang menyebabkan terjadinya tindak pidana kriminal fisik oleh remaja di Kotamadya Medan dan bagaimanakah upaya-upaya yang dilakukan oleh Orang Tua dalam menanggulangi terjadinya tindak pidana kriminal fisik oleh remaja di Kotamadya Medan.
\end{abstract}

\subsection{Teknik Pengumpulan Data}

Metode pengumpulan data dilakukan dengan dua cara yaitu :

\section{Penelitian Kepustakaan (Library} Research)

Yaitu penulis melakukan pengumpulan data dengan cara membaca sejumlah literatur yang relevan dengan tinjauan kriminologi terhadap tindak pidana kriminal fisik oleh remaja, serta bahanbahan normatif berupa produk hukum yaitu Kitab Undang-Undang Hukum Acara Pidana (KUHAP), UndangUndang tindak pidana kriminal fisik.

2. Penelitian di Lapangan (Field Research)

a). Observasi (Observation)

Yaitu penulis mendatangi lokasi penelitian kemudian melakukan pengamatan secara langsung dan seksama terhadap obyek penelitian guna mengetahui faktor-faktor yang mempengaruhi terjadinya tindak pidana kriminal fisik oleh remaja dan upaya-upaya yang dilakukan oleh pihak kepolisian dalam menanggulangi tindak pidana tindak pidana kriminal fisik.

b). Wawancara (Interview)

Yaitu penulis melakukan tanya jawab (interview) kepada sejumlah nara sumber yang berkompeten seperti remaja yang pernah menjadi pelaku dalam tindak pidana kriminal fisik, serta masyarakat, tokoh agama dan tokoh pemuda dalam upaya menanggulangi terjadinya tindak pidana kriminal fisik.

c). Dokumentasi (Documentation) Yaitu penulis melakukan pengumpulan data-data dilokasi penelitian yang berhubungan dengan tindak pidana kriminal fisik oleh remaja dan upaya-upaya yang dilakukan pihak kepolisian dalam menanggulangi terjadinya tindak pidana kriminal fisik oleh remaja.

\subsection{Teknik Analisis Data}

Data penelitian diolah dan dianalisis secara kualitatif yaitu menganalisa data berdasarkan kualitasnya lalu dideskripsikan dengan menggunakan kata-kata sehingga diperoleh bahasan atau paparan dalam bentuk kalimat yang sistematis dan dapat dimengerti, kemudian ditarik kesimpulan. Dapat dilihat pada gambar 2 berikut:

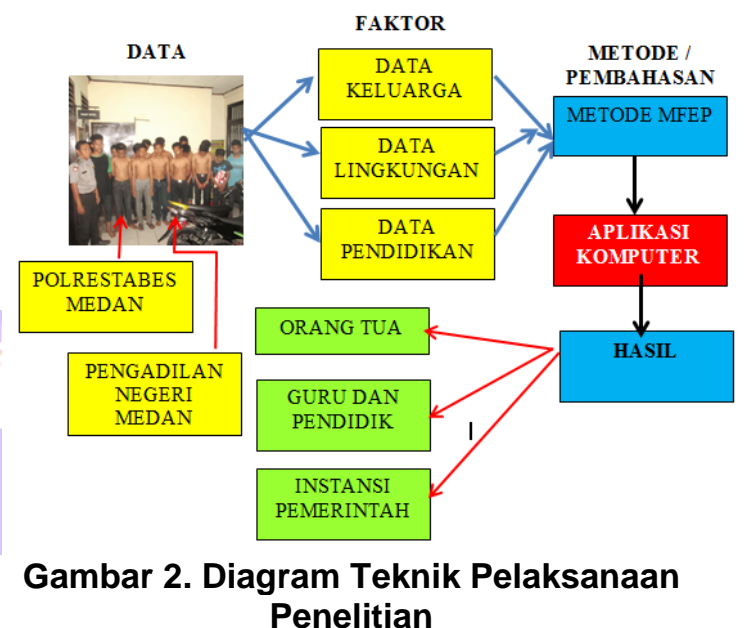

HASIL DAN PEMBAHASAN

Permasalahan serius yang sedang dihadapi adalah masalah kenakalan remaja yang merupakan persoalan aktual dihampir setiap negara di dunia termasuk Indonesia. Saat ini sebagai gambaran merebaknya kasus-kasus pelanggaran hukum yang dilakukan remaja dapat berupa perkelahian, penodongan, perampokan, pencurian, pemilikan senjata tajam bahkan penyalahgunaan narkotika atau berbagai pelanggaran hukum lainnya. Dari beberapa kasus pelanggaran hukum tersebut dapat memberikan gambaran bahwa di era pembangunan manusia seutuhnya, remaja yang mempunyai hak dan kewajiban membangun bangsa dan negara, justru mereka melakukan perbuatan yang melanggar hukum.

Adapun data tindak pidana kriminal untuk remaja usia 18 tahun kebawah menurut data statistik adalah seperti pada gambar 3 berikut: 


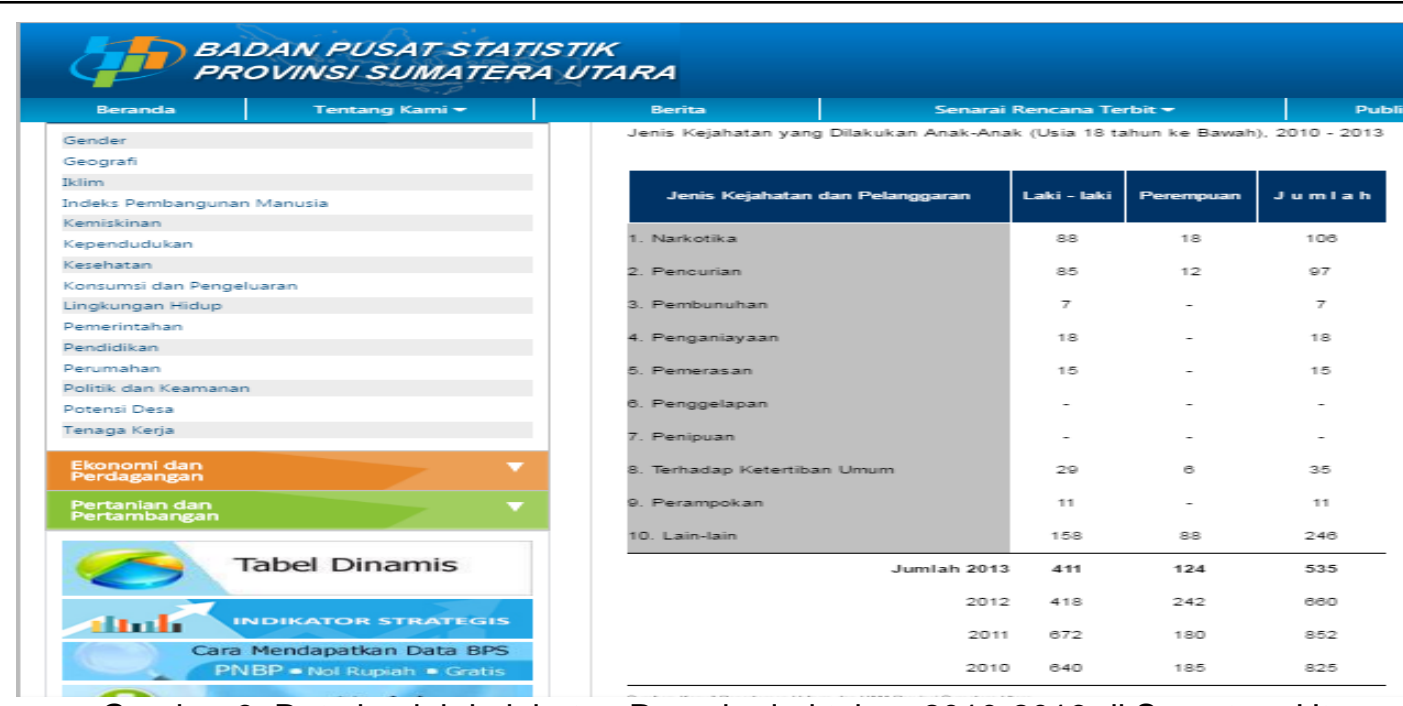

Gambar 3. Data jumlah kejahatan Remaja dari tahun 2010-2013 di Sumatera Utara Sumber : http://sumut.bps.go.id/frontend/linkTabelStatis/view/id/479

Sedangkan menurut data statistik pada tahun 2014 adalah seperti pada gambar 4 berikut:

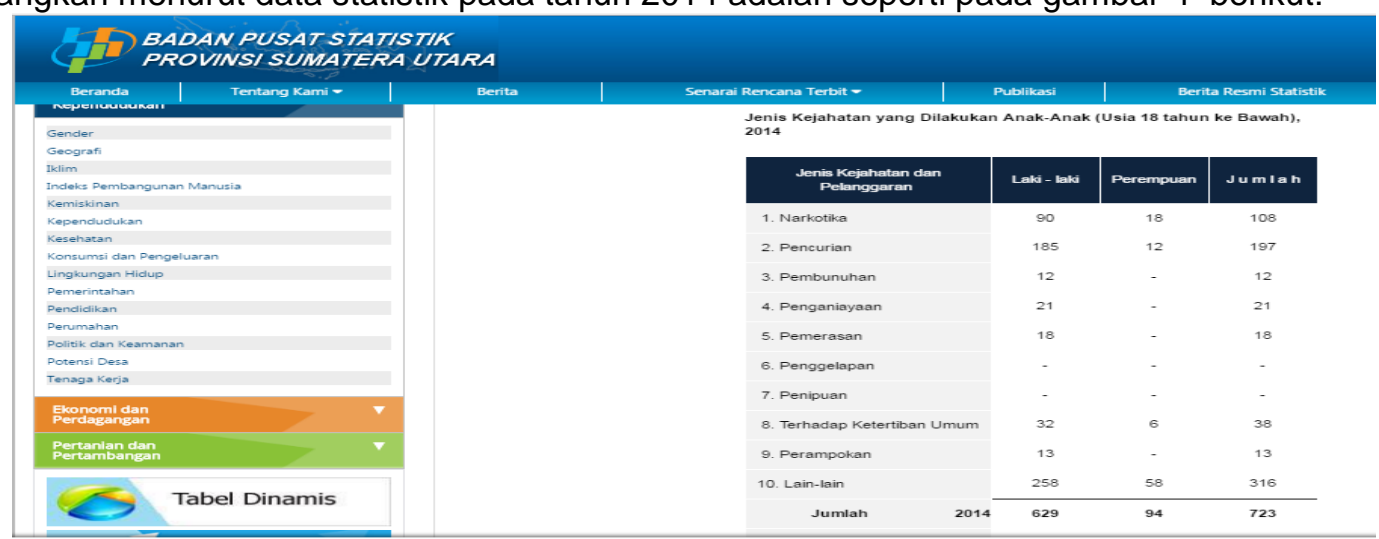

Gambar 4. Data jumlah kejahatan Remaja tahun 2014 di Sumatera Utara Sumber : http://sumut.bps.go.id/frontend/linkTabelStatis/view/id/479

Dari data di atas dapat dilihat pada tahun 2013 sebanyak 535 kasus dan pada tahun 2014 sebanyak 723 kasus, dan berdasarkan data yang ada kenaikan terjadi $\pm 1,35 \%$.

Penyebab terjadinya tindakan kriminal ini disebabkan oleh banyak faktor, tetapi jika faktor-faktor penyebab terjadinya tindakan kejahatan ini diketahui lebih dini oleh pihak orang tua (masyarakat), mungkin orang tua dapat mendidik anaknya dan mengambil sebuah solusi yang tepat dan dengan mengetahui faktor ini sudah tentu akan dapat mengurangi jumlah anak remaja pelaku tindak pidana kriminal fisik. Tindakan kriminal fisik yang dimaksud dalam penelitian ini adalah : Perampokan, Ketertiban Umum, Pencurian dan pembunuhan.

$$
\text { Langkah selanjutnya adalah }
$$
memberikan pembobotan kepada faktorfaktor yang digunakan dimana total pembobotan harus sama dengan 1$)(\Sigma$ pembobotan = 1). Misalnya nilai bobot ditentukan sebagai berikut, 0,20 untuk Umur, 0,45 untuk Tingkat Pendidikan dan 0,35 untuk Status sosial Keluarga , seperti pada tabel 1 berikut:

Tabel 1. Nilai Bobot Untuk Faktor

\begin{tabular}{|l|c|}
\hline \multicolumn{1}{|c|}{ Faktor } & $\begin{array}{c}\text { Nilai } \\
\text { Bobot }\end{array}$ \\
\hline Umur & 0,20 \\
\hline Pendidikan & 0,45 \\
\hline Sosial Keluarga & 0,35 \\
\hline Total & 1 \\
\hline
\end{tabular}

Setelah dilakukan pembobotan, ditetapkan ada 3 kriteria pelaku tindakan pidana yang akan ditimbang, yaitu Umur, Pendidikan dan Status Sosial Keluarga dievaluasi dan diberikan nilai bobot untuk setiap kriterianya seperti tercantum dalam tabel 2 . 
Tabel 2. Nilai Faktor dan Status Penyebab (jumlah kasus)

\begin{tabular}{|c|c|c|c|c|}
\hline $\begin{array}{c}\text { Faktor } \\
\text { Status Potensi }\end{array}$ & Perampokan & $\begin{array}{c}\text { Ketertiban } \\
\text { Umum }\end{array}$ & Pencurian & Pembunuhan \\
\hline Umur (Tahun) & 3 & 3 & 2 & 3 \\
\hline Pendidikan & 4 & 4 & 2 & 4 \\
\hline Sosial Keluarga & 3 & 2 & 2 & 3 \\
\hline
\end{tabular}

Tabel 3. Bobot Umur

\begin{tabular}{|c|c|}
\hline UMUR & $\begin{array}{c}\text { Nilai } \\
\text { Bobot }\end{array}$ \\
\hline $12-14$ & 1 \\
\hline $14-16$ & 2 \\
\hline $16-18$ & 3 \\
\hline
\end{tabular}

Tabel 4. Bobot Pendidikan

\begin{tabular}{|l|c|}
\hline \multicolumn{1}{|c|}{ PENDIDIKAN } & $\begin{array}{c}\text { Nilai } \\
\text { Bobot }\end{array}$ \\
\hline Tidak Sekolah & 4 \\
\hline SD & 3 \\
\hline SMP & 2 \\
\hline SLTA & 1 \\
\hline
\end{tabular}

Tabel 5. Bobot Status Sosial Keluarga

\begin{tabular}{|l|c|}
\hline STATUS SOSIAL & $\begin{array}{c}\text { Nilai } \\
\text { Bobot }\end{array}$ \\
\hline Orang Tua Akur & 1 \\
\hline Tanpa Orang Tua & 2 \\
\hline Broken Home & 3 \\
\hline
\end{tabular}

Proses perhitungan weight evaluation merupakan perhitungan antara factor weight dan factor evaluation dengan penjumlahan, dari hasil weight evaluation dapat menentukan hasil evaluasi. Berikut adalah perhitungan weight evaluation pada alternative status potensi.

a. Weight Evaluation Umur

$\mathrm{WE}=\mathrm{FW} \times \mathrm{E}$

$W_{1}=3 \times 0.2=0.6$

$\mathrm{W}_{2}=3 \times 0.2=0.6$

$\mathrm{W}_{3}=2 \times 0.2=0.4$

$\mathrm{W}_{4}=3 \times 0.2=0.6$

b. Weight Evaluation Pendidikan

$\mathrm{WE}=\mathrm{FW} \times \mathrm{E}$

$W_{1}=4 \times 0.45=1.8$

$W_{2}=4 \times 0.45=1.8$

$W_{3}=2 \times 0.45=0.9$

$W_{4}=4 \times 0.2=1.8$

c. Weight Evaluation Sosial Keluarga

$\mathrm{WE}=\mathrm{FW} \times \mathrm{E}$

$W_{1}=3 \times 0.35=1.05$

$W_{2}=2 \times 0.35=0.7$

$W_{3}=2 \times 0.35=0.7$

$\mathrm{W}_{4}=3 \times 0.2=1.05$

Dari hasil perhitungan tersebut diperoleh nilai weight evaluation dapat dilihat pada tabel berikut:

Tabel 6. Hasil Perhitungan Evaluation Factor

\begin{tabular}{|l|c|c|c|c|}
\hline $\begin{array}{r}\text { Faktor } \\
\text { Status Penyebab }\end{array}$ & Perampokan & $\begin{array}{c}\text { Ketertiban } \\
\text { Umum }\end{array}$ & Pencurian & Pembunuhan \\
\hline Umur (Tahun) & 0.6 & 0.6 & 0.4 & 0.6 \\
\hline Pendidikan & 1.8 & 1.8 & 0.9 & 1.8 \\
\hline Sosial Keluarga & 1.05 & 0.7 & 0.7 & 1.05 \\
\hline
\end{tabular}

Menjumlahkan seluruh hasil weight evaluation untuk memperoleh total evalusi

$\sum_{i=1}^{n} W E_{1}=W E_{1}+W E_{2}+\cdots+W E_{n}$

$\sum \mathrm{W}_{1}=0.6+0.6+0.4+0.6=2.2$

$\sum \mathrm{W}_{2}=1.8+1.8+0.9+1.8=6.3$

$\Sigma \mathrm{W}_{3}=1.05+0.7+0.7+1.05=3.5$

Dari hasil perhitungan di atas dapat disimpulkan tingkat pendidikan baik di rumah dan di sekolah adalah menjadi factor utama penyebab terjadinya tidak pidana bagi anak remaja yakni dengan nilai 6.3 .

\section{KESIMPULAN}

Berdasarkan perhitungan serta perancangan sistem yang telah dilakukan, maka dapat disimpulkan bahwa pengambilan keputusan penentuan faktor remaja melakukan tindak pidana menggunakan metode Multi Factor Evaluation Process. Beberapa hal yang perlu digaris bawahi antara lain:

1) Berdasarkan perhitungan metode MFEP di dapatkan hasil bahwa tingkat pendidikan merupakan penyebab terbanyak terjadi kriminal. 
2) Pemberian bobot faktor kriteria dapat mempengaruhi penilaian dan hasil perhitungan metode MFEP.

3) Penelitian ini masih menggunakan 2 faktor berdasarkan observasi penulis dilapangan, faktor tersebut dapat dikembangkan menjadi lebih agar penelitian ini dapat menghasilkan penilaian yang efektif.

\section{DAFTAR PUSTAKA}

[1]. Abussalam, 2007, Kriminologi, Restu Agung, Jakarta.

[2]. Ahmad Khaidir. 2014 "Sistem Pendukung Keputusan Penyeleksian Calon Siswa Baru SMA 1 Badar Dengan Metode Multifactor Evaluation Process". 2301-9425

[3]. Abintoro Prakoso, Kriminologi dan Hukum Pidana, Yogyakarta, Laksbang Grafika, 2013, hlm. 14.

[4]. Indah Sri Utari.Aliran dan Teori Dalam Kriminologi. Yogyakart. Thafa Media. 2012. HIm. 20

[5]. Gatot Supramono, 2000, Hukum Acara Pengadilan Anak, Djambatan, Jakarta.

[6]. Tonni Limbong, 2013. Implementasi Metode Simple Additive Weighting (SAW) Untuk Pemilihan Pekerjaan Bidang Informatika, STMIK Budi Darma

[7]. Kanter dan Sianturi, 2002, Asas-asas Hukum Pidana di Indonesia dan Penerapannya. Storia Grafika, Jakarta

[8]. Monks, F.J,K \& Haditono, S.R. 1999. Psikologi Perkembangan. Gadjah Mada University Press, Yogyakarta, 2010.

[9]. Muhammad, Ishaq, Umi. 2012 "Sistem Pendukung Keputusan Seleksi Calon POLRI Baru Kota Medan Menggunakan Metode Multifactor Evaluation Process (MFEP)". 1978-6603.

[10]. Render, B. dan Stair,M.R,Jr. 2002. Quanitative Analysis For Management. Prentice Hall.

[11]. Sarwono, S.W. 2002. Psikologi Remaja. Edisi Enam, Raja Grafindo Persada, Jakarta.

[12]. Topo Santoso, 2001, Menggagas Hukum Pidana Islam, Penerapan Hukum Pidana Islam dalam Konteks Modernitas, Asy-Syaamil Press dan Grafika, Jakarta.

[13]. Wibowo, Henry., Amalia, Riska., Andi Fadlun M., Kurnia Arivanti (2009). "Sistem Pendukung Keputusan Untuk Menentukan Penerima Beasiswa Bank BRI Menggunakan FMADM", 907-5022.

[14]. Kitab Undang-Undang Hukum Acara Pidana (KUHAP)
[15]. http://ojs.amikom.ac.id/index.php/semna steknomedia/article/view/1419. Seminar Nasional Teknologi Informasi dan Multimedia 2016, ISSN : : 2302-3805, Hal : 123-126.

[16]. http://komputa.if.unikom.ac.id/_s/data/ju $\mathrm{rnal} / \mathrm{vol} .3-n o .2 / 1.3 \cdot 2.10 .2014-50-57-$ 2089-9033.pdf/pdf/1.3.2.10.2014-50-572089-9033.pdf. Jurnal IImiah Komputer dan Informatika (KOMPUTA), Vol. 3, No. 2, Oktober 2014, ISSN : 2089-9033, Hal : 50 -57. 